\title{
In Vitro Activation of a Transcription Factor by Gamma Interferon Requires a Membrane-Associated Tyrosine Kinase and Is Mimicked by Vanadate
}

\author{
KEN-ICHI IGARASHI, MICHAEL DAVID, ANDREW C. LARNER, AND DAVID S. FINBLOOM* \\ Division of Cytokine Biology, Center for Biologics Evaluation and Research, Food and \\ Drug Administration, 8800 Rockville Pike, Bethesda, Maryland 20892
}

Received 18 February 1993/Returned for modification 25 March 1993/Accepted 7 April 1993

\begin{abstract}
Gamma interferon (IFN- $\boldsymbol{\gamma}$ ) activates the formation of a DNA-binding protein complex (FcRF $\boldsymbol{\gamma}$ ) that recognizes the gamma response region (GRR) of the promoter for the human high-afinity Fcy receptor. In a membrane-enriched fraction prepared from human peripheral blood monocytes, IFN- $\gamma$ activation of FcRF $\gamma$ occurred within 1 min and was ATP dependent. Activation of FCRF $\gamma$ required a tyrosine kinase activity, and recognition of the GRR sequence by FcRF $\gamma$ could be abrogated by treatment with a tyrosine-specific protein phosphatase. Treatment of cells with vanadate alone resulted in the formation of FcRF $\gamma$ without the need for IFN- $\gamma$. UV cross-linking and antibody competition experiments demonstrated that the FcRF $\gamma$ complex was composed of at least two components: the 91-kDa protein of the IFN- $\alpha$-induced transcription complex ISGF3 and a 43-kDa component that bound directly to the GRR. Therefore, specificity for IFN-induced transcriptional activation of early response genes requires at least two events: (i) ligand-induced activation of membrane-associated protein by tyrosine phosphorylation and (ii) formation of a complex composed of an activated membrane protein(s) and a sequence-specific DNA-binding component.
\end{abstract}

The activation of macrophages and monocytes by gamma interferon (IFN- $\gamma$ ) is critical for host defense against a variety of microorganisms (17). One of the key responses induced by IFN- $\gamma$ is the induction of high-affinity receptors for the Fc portion of immunoglobulin G (FcyRI). These receptors are involved in phagocytosis, oxidative burst, and antibody- dependent-mediated cytotoxicity in phagocytic cells (for a review, see references 16, 21, and 26). The gene for the FcyRI is transcriptionally activated within minutes by IFN- $\gamma$ in human monocytes such that steady-state levels of FcyRI mRNA increase within 30 min after exposure to IFN- $\gamma$. Transfection studies have defined a gamma response region (GRR) within the promoter of the Fc $\gamma$ RI gene that is responsible for IFN- $\gamma$ induction of the gene (19). An IFN- $\gamma$ activated DNA-binding complex (FcRF $\gamma$ ) can be observed in the nuclear extracts of IFN- $\gamma$-treated monocytes that specifically recognizes the GRR sequence (28). Following exposure to IFN- $\gamma$, FCRF $\gamma$ is formed within seconds, with maximal induction after 10 to $20 \mathrm{~min}$.

We have recently developed an in vitro system in order to study transmembrane signaling of the IFN- $\alpha$-activated transcription factor, interferon-stimulated gene factor 3 (ISGF3) (3). Results from these studies suggest that both a tyrosine kinase and a tyrosine phosphatase activity are necessary for formation of ISGF3 (4). Activation by IFN- $\gamma$ of the transcription factor GAF (gamma activating factor), which binds to the promoter of the guanylate binding protein gene (5), also requires a tyrosine kinase and phosphatase (15). We have now adopted this in vitro system with a membraneenriched fraction prepared from human peripheral blood monocytes in order to define in more detail the events governing the activation of FcRF $\gamma$ by IFN- $\gamma$.

\footnotetext{
${ }^{*}$ Corresponding author.
}

\section{MATERIALS AND METHODS}

Cells. Human monocytes were purified from leukopacks prepared by leukapheresis of normal volunteers by FicollHypaque sedimentation and then countercurrent centrifugal elutriation. Monocytes ( $>95 \%$ pure) were cultured in Dulbecco's modified Eagle medium (GIBCO, Grand Island, N.Y.) supplemented with $10 \%$ human $\mathrm{AB}$ serum (Sigma Chemical Co., St. Louis, Mo.) with $60 \mathrm{U}$ of granulocyte macrophage colony-stimulating factor (GMCSF) per ml (20 $\times 10^{7} \mathrm{U} / \mathrm{mg}$ ) (kindly supplied by Schering Corp., Kenilworth, N.J.) for 4 to 6 days. After 4 days in culture with granulocyte macrophage colony-stimulating factor, monocytes express 7 - to 10 -fold more IFN- $\gamma$ receptors and increase in size, thereby making them more suitable for membrane preparations (6).

Preparation of cell membranes. Monocytes were harvested by scraping into media and washed in phosphate-buffered saline. The cell pellet consisting of $2 \times 10^{8}$ to $3 \times 10^{8}$ cells was resuspended in a 1.5-fold volume of reaction buffer (100 $\mathrm{mM} \mathrm{NaF}$ or $\mathrm{NaCl} ; 20 \mathrm{mM} \mathrm{MgCl}$; $4 \mathrm{mM} \mathrm{ATP;} 200 \mu \mathrm{M}$ sodium ascorbate; $30 \mu \mathrm{g}$ of pyruvate kinase per $\mathrm{ml} ; 12$ mM pyruvate; $100 \mathrm{mM} N$-2-hydroxyethylpiperazine- $N^{\prime}-2$ ethanesulfonic acid [HEPES; pH 7.9]; leupeptin, aprotinin, and pepstatin, each at $5 \mu \mathrm{g} / \mathrm{ml} ; 600 \mu \mathrm{M}$ phenylmethylsulfonyl fluoride) and lysed in a stainless steel Dounce homogenizer. The resulting cell lysate was centrifuged at $3,000 \times g$ for $7 \mathrm{~min}$ at $4^{\circ} \mathrm{C}$ over a $38 \%$ sucrose cushion to sediment nuclei. The postnuclear lysate was then centrifuged for 10 $\min$ at $4^{\circ} \mathrm{C}$ at $13,000 \times g$ in order to sediment cellular membranes. The membrane pellet was then washed $(20 \mathrm{mM}$ $\mathrm{MgCl}_{2}, 100 \mathrm{mM}$ HEPES, $200 \mu \mathrm{M}$ ascorbate, and $600 \mu \mathrm{M}$ phenylmethylsulfonyl fluoride) and resuspended in reaction buffer to which IFN- $\gamma$ was added at $200 \mathrm{ng} / \mathrm{ml}$ for $20 \mathrm{~min}$ at $30^{\circ} \mathrm{C}$. The reaction was terminated by the addition of Nonidet P-40 or Triton X-100 to a final concentration of $0.1 \%$. The solution was then centrifuged at $13,000 \times g$ for $3 \mathrm{~min}$, and the supernatant was incubated with a ${ }^{32} \mathrm{P}$-end-labeled dou- 
ble-stranded oligonucleotide consisting of the GRR, 5'AGC ATGTTTCAAGGATTTGAGATGTATTTCCCAGAAA AG $3^{\prime}$, as previously described $(19,28)$. For those studies evaluating the role of ATP, membranes were resuspended in reaction buffer lacking ATP and pyruvate kinase. To this membrane preparation, IFN- $\gamma$ was added, and to a parallel tube, IFN- $\gamma$ plus ATP and pyruvate kinase was added.

Electrophoretic mobility shift assays (EMSA). The complex of FcRFy and ${ }^{32} \mathrm{P}$-GRR were then separated on a $6 \%$ nondenaturing polyacrylamide gel as previously described (28).

Solution hybridization and RNase mapping. Total cellular RNA ( 5 to $10 \mu \mathrm{g}$ ) was hybridized with $10^{5} \mathrm{cpm}$ of ${ }^{32} \mathrm{P}$-labeled antisense RNA probe in $80 \%$ (vol/vol) formamide, $40 \mathrm{mM}$ piperazine- $N, N^{\prime}$-bis(2-ethanesulfonic acid), $0.4 \mathrm{M} \mathrm{NaCl}$, and $1 \mathrm{mM}$ EDTA at $56^{\circ} \mathrm{C}$ for 16 to $20 \mathrm{~h}$, and the protected RNA was analyzed as previously described $(20,28)$. ISG54 RNA was assayed with a $367-b p$ EcoRI probe corresponding to a portion of the second exon of the ISG54 gene. The size of the protected fragment is $367 \mathrm{bp}$. The riboprobe from the GBP gene (2) (kindly provided by E. Y. Cheng, Dupont, Wilmington, Del.) was prepared by linearizing the cDNA with $B g l I I$, yielding a protected fragment of $512 \mathrm{bp}$. As an internal control, samples were simultaneously hybridized to a rat GAPDH. This 1,400-bp Pst fragment of the cDNA was subcloned into pGEM1, and the size of the protected fragment is 320 bp. ${ }^{32} \mathrm{P}$-antisense RNA was transcribed from each of the probes with either Sp6 or T7 RNA polymerase.

\section{RESULTS}

In order to facilitate preparation of membranes, we utilized purified human peripheral blood monocytes that were cultured in granulocyte macrophage colony-stimulating factor for 4 to 6 days. These cells responded as well as fresh monocytes with regard to IFN- $\gamma$ induction of FcRFy (5). Cells were homogenized, the homogenate was centrifuged over a $38 \%$ sucrose cushion, and the remaining membranes were sedimented from the nucleus-free supernatant, washed, and resuspended in reaction buffer. With lactate dehydrogenase as an enzymatic marker, these membrane preparations contained less than $5 \%$ contaminating cytosol and did not support the formation of ISGF3 by IFN- $\alpha$, which is dependent upon the cytosolic factor (ISGF3 $\gamma$ ) in order to form the complete complex (data not shown). IFN- $\gamma$-induced formation of FcRF $\gamma$ was then assayed by EMSA (Fig. 1) with a whole-cell lysate (lanes 1 and 2), the supernatant fraction (lanes 3 and 4), and the membrane fraction (lanes 5 and 6). IFN- $\gamma$ induced the formation of FcRF $\gamma$ both in the whole-cell homogenate and in the membrane-enriched fraction but not in the membrane-depleted supernatant fraction. Therefore, in contrast to the activation of ISGF3 by IFN- $\alpha$, all the components necessary for IFN- $\gamma$ induction of FcRF $\gamma$ were retained in the membrane-enriched fraction. Prior incubation of membranes with a monoclonal antibody $(\gamma R 38)$ (8) against the IFN- $\gamma$ receptor abrogated formation of FCRF $\gamma$ (Fig. 1, lanes 7 to 9), confirming that activation of FcRF $\gamma$ required the IFN- $\gamma$ receptor.

Activation of the FCRF $\gamma$ complex occurred within minutes following IFN- $\gamma$ binding to intact monocytes (28), and the kinetics of IFN- $\gamma$-induced FcRF $\gamma$ on isolated membranes paralleled that seen in intact cells (Fig. 2). On membranes, FcRF $\gamma$ could be observed within $60 \mathrm{~s}$ after exposure to IFN- $\gamma$ (lanes 1 vs 2), and maximal induction occurred within 15 min (lane 6). FcRF $\gamma$ bound to the GRR specifically such that only an oligonucleotide consisting of the GRR of the

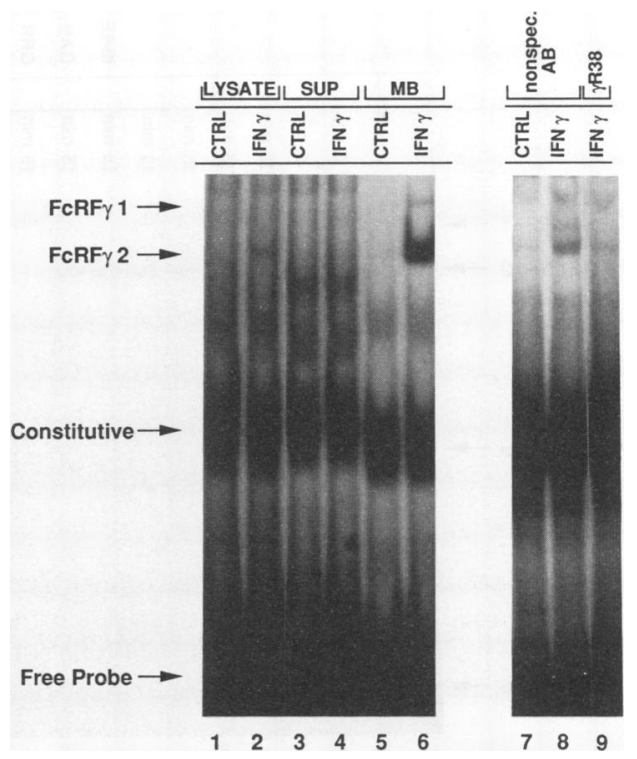

FIG. 1. IFN- $\gamma$ induces the formation of FcRF $\gamma$ on monocytederived cellular membranes. Monocytes and membranes were prepared as described in Materials and Methods and treated with or without IFN- $\gamma$, and the formation of FcRF $\gamma$ was assessed by EMSA. Control (CTRL) versus IFN- $\gamma$ treatment: entire cell lysate (lanes 1 and 2, respectively), supernatant (SUP) remaining after centrifugation of membranes (lanes 3 and 4, respectively), and enriched membrane (MB) preparation (lanes 5 and 6, respectively). The decreased signal in lane 2 is the result of a dilution of the sample. There was a donor-to-donor variation in the signal intensity of FcRF $\gamma$ with the different monocyte preparations. A monoclonal antibody $(\gamma \mathrm{R} 38)$ directed against the ligand-binding epitope of the IFN- $\gamma$ receptor was incubated with membranes for 1 to $2 \mathrm{~h}$ at $4^{\circ} \mathrm{C}$ prior to the addition of IFN- $\gamma(20 \mathrm{ng} / \mathrm{ml})$ for $20 \mathrm{~min}$ at $30^{\circ} \mathrm{C}$ (lanes 7 to 9). nonspec. $A B$, nonspecific antibody.

FcyRI promoter inhibited FcRF $\gamma$ formation (Fig. 2, lane 11). There was no inhibition by the gamma activating sequence from the IFN- $\gamma$-induced gene, guanylate-binding protein (Fig. 2, lane 10). An oligonucleotide containing the IFNstimulated response element (ISRE) from the ISG54 gene inhibited binding of the constitutive band but had no effect on FcRFy (Fig. 2, lane 9). These findings were similar to those observed with nuclear extracts prepared from IFN- $\gamma$ treated monocytes assayed for FcRF $\gamma$ binding to the GRR (28).

Since in vitro formation of ISGF3 by IFN- $\alpha$ and GAF by IFN- $\gamma$ required ATP $(3,14)$, similar studies were performed with respect to FcRF $\gamma$ activation by IFN- $\gamma$. There was marked attenuation of FCRF $\gamma$ formation when membranes were prepared in the absence of exogenous ATP and incubated with IFN- $\gamma$ (Fig. 3a, lane 3). The addition of ATP restored the ability of IFN- $\gamma$ to activate FcRF $\gamma$ (Fig. 3a, lane $2)$. If adenylyl ( $\beta, \gamma$-methylene)-diphosphonate (AMP-PCP), a nonhydrolyzable ATP analog, was added instead of ATP, the generation of FcRF $\gamma$ was also completely abrogated (Fig. 3a, lane 4). These findings suggested that a phosphorylation reaction was required for the IFN- $\gamma$-induced activation of this protein-DNA complex. In order to better define the class of kinase necessary for the activation of FcRF $\gamma$, we measured the effect of two protein kinase inhibitors on IFN- $\gamma$-induced formation of FcRF $\gamma$ in our cell-free system. At concentrations $(500 \mathrm{nM})$ that inhibit most serine, threonine and tyrosine kinase reactions, staurosporin inhibited 


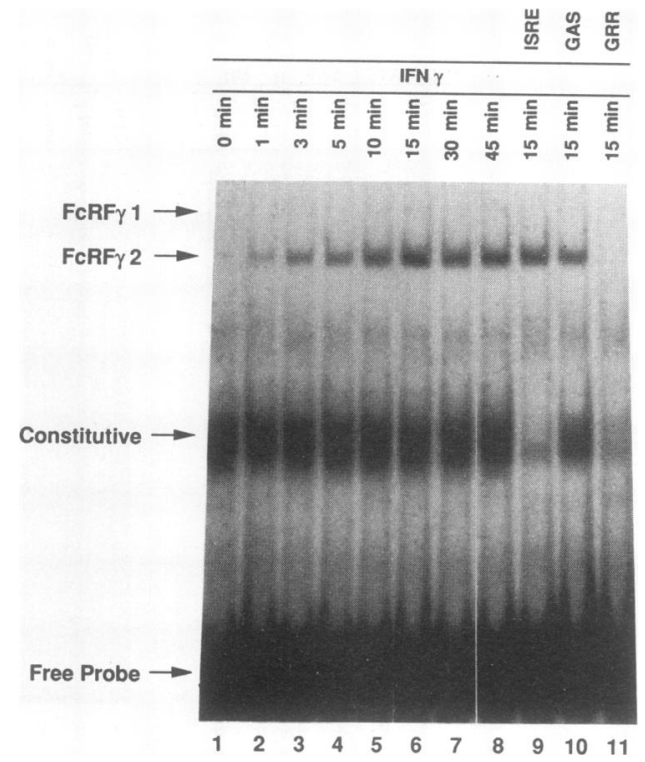

FIG. 2. Kinetics of the IFN- $\gamma$-induced formation of FcRF $\gamma$. Enriched cellular membranes were treated with IFN- $\gamma$ for various times, and the formation of FCRF $\gamma$ was assessed by EMSA. Specificity of FcRF $\gamma$ generated on membranes was determined by incubation of ${ }^{32} \mathrm{P}$-GRR with or without the presence of a 100 -fold molar excess of the following unlabeled oligonucleotides: the ISRE of the ISG54 gene (18) (lane 9), the ISRE/GAS element of the GBP gene (4) (lane 10), and the GRR element (17) (lane 11).
IFN- $\gamma$-induced FcRF $\gamma 1$ and 2 (Fig. 3b, lanes 1 to 3). Lower concentrations of staurosporin $(10 \mathrm{nM})$ which are known to specifically inhibit protein kinase $\mathrm{C}$ were ineffective (data not shown). Genistein, a specific tyrosine kinase inhibitor, prevented the formation of FcRF 11 but was without effect on the formation of FcRFy2 (Fig. 3b, lanes 4 to 6). Both of these findings were consistent with experiments using intact cells. Staurosporin at $500 \mathrm{nM}$ virtually completely prevented the activation of FcRF $\gamma 1$ and FcRF $\gamma 2$, whereas genistein only partially inhibited the formation of FcRF $\gamma$ (27 and unpublished observations). These findings suggested that activation of FcRF $y 1$ and -2 required a kinase activity that was at least in part tyrosine kinase mediated. However, the involvement of other classes of kinases could not be ruled out. To determine if phosphorylated tyrosines in the proteins of the activated FcRF $\gamma$ complex were necessary for recognition of the GRR element, we treated GRR affinity-purified FcRF $\gamma$ with a recombinant protein tyrosine phosphatase from Yersinia enterocolitica (12). Treatment of purified FcRF $\gamma$ with this tyrosine phosphatase destroyed the ability of the complex to recognize the GRR (Fig. 3c, lanes 1 and 2). Addition of vanadate (a tyrosine phosphatase inhibitor) markedly diminished the effect (Fig. 3c, lane 3).

Recent studies have indicated that formation of GAF by IFN- $\gamma$ required a ligand-activated tyrosine kinase and phosphatase activity (15). We therefore examined the potential role of tyrosine phosphatases by the addition of vanadate to monocyte membranes. In contrast to its ability to inhibit IFN- $\alpha$-induced ISGF3 in HeLa cell membranes (4), vanadate enhanced IFN- $\gamma$ activation of FcRF $\gamma$ (data not shown). Furthermore, in a membrane fraction, vanadate treatment alone resulted in the formation of FcRF $\gamma$ to a level equiva-

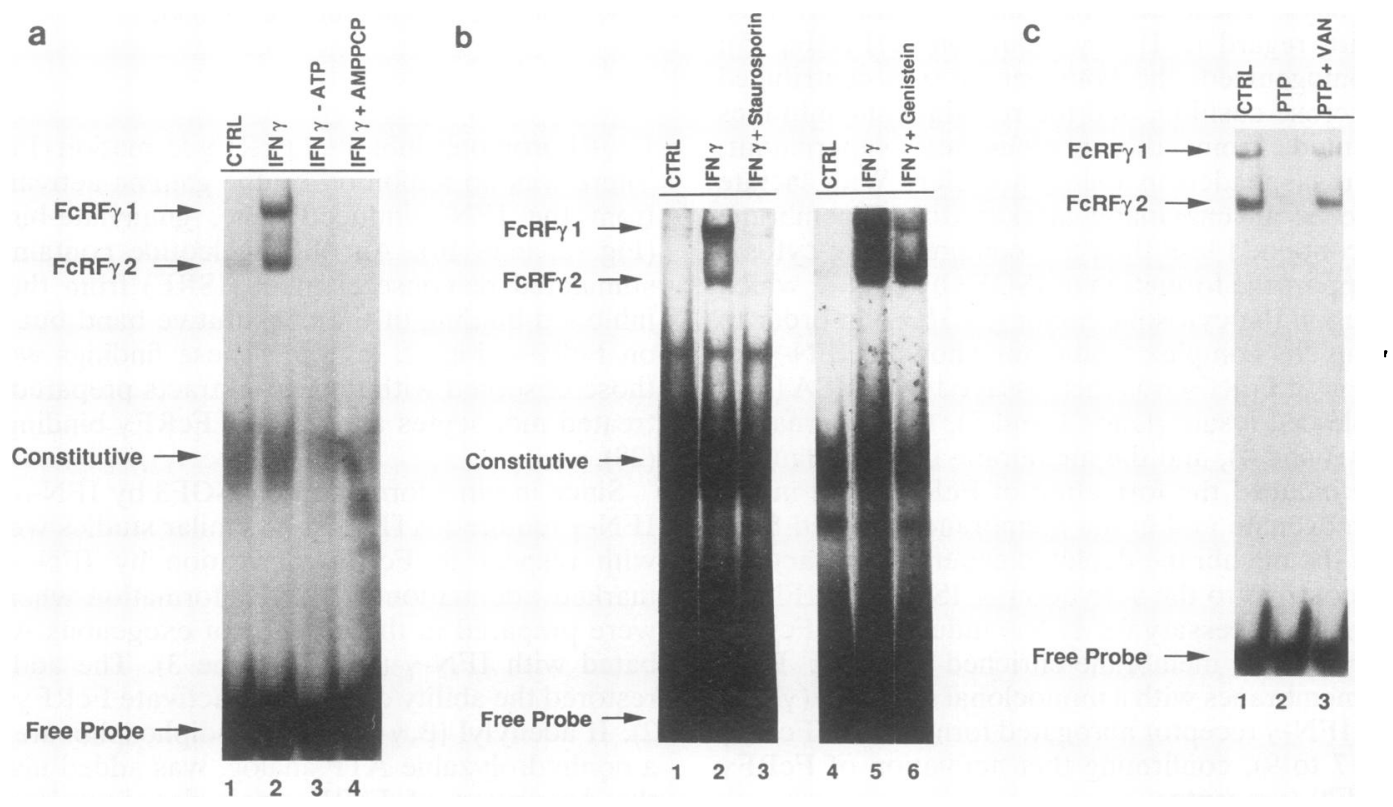

FIG. 3. Formation of IFN- $\gamma$-induced FcRF $\gamma$ requires a tyrosine kinase activity. (a) IFN- $\gamma$-treated membranes were incubated with (lane 2) or without ATP (lane 3) or ATP was replaced with a nonhydrolyzable ATP analog, adenylyl ( $\beta, \gamma$-methylene)-diphosphonate (AMP-PCP) (lane 4), and the formation of FcRF $\gamma$ was determined by EMSA. (b) Membranes were incubated with staurosporin (500 nM) (lane 3) or genistein $\left(100 \mu \mathrm{g} / \mathrm{ml}\right.$ ) (lane 6) for $5 \mathrm{~min}$ at $30^{\circ} \mathrm{C}$ prior to the addition of IFN- $\gamma$. (c) FcRFy was highly purified with a combination of heparin-Sepharose chromatography and then by specific affinity chromatography with a GRR oligonucleotide column. Protein concentration was less than $1 \mu \mathrm{g} / \mathrm{ml}$, and the estimated specific activity was at least 5,000-fold greater compared with that of crude extracts. Purified FcRF $\gamma$ was incubated with $1 \mu \mathrm{g}$ of recombinant protein tyrosine phosphatase (derived from $Y$. enterocolitica) for $30 \mathrm{~min}$ at $30^{\circ} \mathrm{C}$ alone (lane 2 ) or in combination with vanadate (lane 3). ${ }^{32}$ P-GRR was then added, and the reaction mixture was assayed by EMSA for FcRF $\gamma$ formation. CTRL, control; VAN, vanadate. 


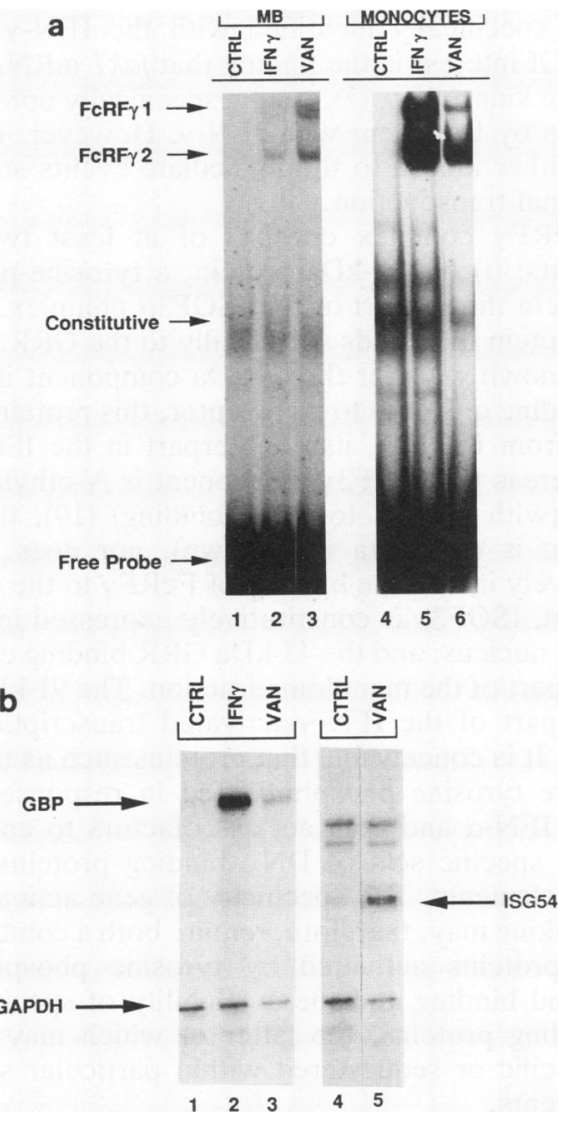

FIG. 4. Treatment of monocyte membranes (MB) and intact cells with vanadate (VAN) results in the activation of FcRFy and induction of some IFN-induced cellular RNAs. (a) Membranes were incubated with either IFN- $\gamma(200 \mathrm{ng} / \mathrm{ml})$ (lane 2$)$ or vanadate $(1 \mathrm{mM})$ (lane 3) for $20 \mathrm{~min}$ at $30^{\circ} \mathrm{C}$, and the formation of FcRF $\gamma$ was measured. For intact monocytes, cells were incubated for $30 \mathrm{~min}$ at $37^{\circ} \mathrm{C}$ with either $5 \mathrm{ng}$ of IFN- $\gamma$ per $\mathrm{ml}$ (lane 5 ) or vanadate $(1 \mathrm{mM})$ plus $\mathrm{H}_{2} \mathrm{O}_{2}(2 \mathrm{mM})$ (lane 6). Nuclear extracts were then prepared and assayed for FcRF $\gamma$ by EMSA. (b) Intact cells were incubated with $500 \mu \mathrm{M} \mathrm{H}_{2} \mathrm{O}_{2}$ and $100 \mu \mathrm{M}$ vanadate or $10 \mathrm{ng}$ of IFN- $\gamma$ per $\mathrm{ml}$ for 1.5 $\mathrm{h}$ at $37^{\circ} \mathrm{C}$, and total cellular RNA was isolated for assay by RNase protection for ISG54 or GBP. CTRL, control.

lent to that of IFN- $\gamma$ (Fig. $4 a$, lanes 1 to 3 ). Vanadate treatment of monocyte membranes also resulted in the activation of the transcription complex, ISGF3, which recognizes the IFN- $\alpha$-stimulated response element, ISRE (data not shown). In addition, exposure of intact monocytes to the combination of vanadate and $\mathrm{H}_{2} \mathrm{O}_{2}$ resulted in activation of FcRF $\gamma$ (Fig. 4a, lanes 4 to 6). We next examined whether there was an increase in specific cellular gene mRNA in monocytes that were treated with the combination of vanadate and $\mathrm{H}_{2} \mathrm{O}_{2}$. Although there was no enhancement of steady-state levels of RNA for the FcyRI gene in response to the combined treatment (data not shown), there were increased concentrations of GBP and ISG54 RNAs (Fig. 4b), both of which contain an ISRE in their promoter region. Although vanadate is generally known to inhibit protein tyrosine phosphatases (9), it may also directly stimulate protein tyrosine kinases such that some insulin-regulated signaling events can be mimicked by this agent $(13,14,25)$. It therefore remains unclear whether vanadate activates FcRF $\gamma$ and induces ISG54 and GBP mRNA by decreasing

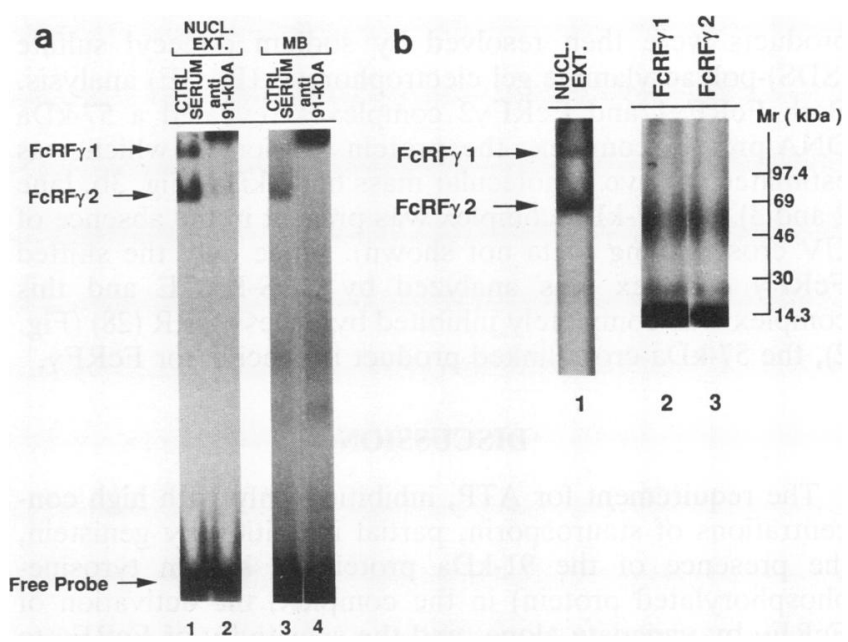

FIG. 5. The FcRF $\gamma$ complex contains the $91-\mathrm{kDa}$ protein (ISGF3, $91 \mathrm{kDa}$ ) and a 43-kDa protein which interacts directly with the GRR. (a) Anti-91-kDa protein antibodies were prepared as described in the text. These antibodies in the form of antisera or control rabbit serum (CTRL SERUM) were incubated with FCRFy generated either from nuclear extracts (NUCL. EXT.; lanes 1 and 2) or isolated membranes (MB; lanes 3 and 4) for $1 \mathrm{~h}$ at $4^{\circ} \mathrm{C}$. The resulting material was then assayed by EMSA. (b) Nuclear extract containing FcRF $\gamma$ was separated by EMSA (lane 1). The entire gel was then UV cross-linked for $20 \mathrm{~min}$ in a Stratagene. Stratalinker. A 1-h exposed autoradiograph of the gel was obtained, and the area of the gel corresponding to the shifted FcRF 11 and FcRF $\gamma 2$ was excised, equilibrated in SDS sample buffer, and placed into the wells of an SDS-polyacrylamide gel (lanes 2 and 3). During the electrophoretic elution of the cross-linked sample from the EMSA gel into the SDS gel, the cross-linked product tends to migrate along the margin of the lanes.

the activity of constitutively active tyrosine phosphatases or by enhancing the activity of a tyrosine kinase. Alternatively, an indirect effect of vanadate cannot be absolutely excluded. Nevertheless, this is the first example of any agent that can induce a response which specifically requires the binding of IFN- $\boldsymbol{\gamma}$ or IFN- $\alpha$ to their respective receptors.

It has recently been established that ISGF3 $\alpha$ consists of three proteins (molecular masses of 113,91 , and $84 \mathrm{kDa}$ ) that are tyrosine phosphorylated in response to IFN- $\alpha$ (23). To form the complete complex, these three proteins interact with ISGF3 $\gamma(48 \mathrm{kDa})$, which is necessary for binding to the ISRE. The $91-\mathrm{kDa}$ protein is also phosphorylated in response to IFN- $\gamma(23,24)$. In order to determine if the $91-\mathrm{kDa}$ protein is a component of FcRF $\gamma$, we prepared antibodies directed against the 39 carboxy-terminal amino acids of the 91-kDa protein (22). Incubation of FcRF $\gamma$ generated from either IFN- $\boldsymbol{\gamma}$-activated nuclear extracts prepared from intact cells (Fig. 5a, lanes 1 and 2) or from membranes (Fig. 5a, lanes 3 and 4) with these antibodies prior to addition of 32P-GRR induced a "supershift" of both FcRFyl and FcRF 2 . The supershift could be abrogated by the addition of antigenic peptide (data not shown). These data provide evidence that the $91-\mathrm{kDa}$ protein is a component of both shifted complexes and support a potential mechanism by which certain genes can be induced by both IFN- $\alpha$ and IFN- $\gamma$. To determine if the FcRF $\gamma$ complex consisted of another component that specifically recognized the GRR element in a manner similar to ISGF3 $\gamma$ for the ISRE sequence, we UV cross-linked both FcRF $\gamma 1$ and FcRF $\gamma 2$ after separation by EMSA (Fig. 5b, lane 1). The cross-linked 
products were then resolved by sodium dodecyl sulfate (SDS)-polyacrylamide gel electrophoresis (PAGE) analysis. Both FcRF $\gamma 1$ and FcRF $\gamma 2$ complexes revealed a $57-\mathrm{kDa}$ DNA-protein complex, the protein portion of which was estimated to have a molecular mass of $43 \mathrm{kDa}$ (Fig. $3 \mathrm{~b}$, lane 2 and 3). No 57-kDa complex was present in the absence of UV cross-linking (data not shown). Since only the shifted FcRF $\gamma$ complex was analyzed by SDS-PAGE and this complex was completely inhibited by excess GRR (28) (Fig. 2 ), the $57-\mathrm{kDa}$ cross-linked product is specific for FcRF $\gamma$.

\section{DISCUSSION}

The requirement for ATP, inhibition only with high concentrations of staurosporin, partial inhibition by genistein, the presence of the $91-\mathrm{kDa}$ protein (a known tyrosinephosphorylated protein) in the complex, the activation of FcRF $\gamma$ by vanadate alone, and the sensitivity of FcRF $\gamma$ to protein tyrosine phosphatase treatment-all indicate the need for a ligand-induced tyrosine kinase activity for FcRF $\gamma$ activation by IFN- $\gamma$. The finding that genistein only partially inhibited the formation of FcRF $\gamma$ probably reflects the selective nature of genistein's action on tyrosine kinases. For instance, genistein had essentially no effect on T-cell signalling, which is well characterized as mediated by receptor-associated tyrosine kinases (10). The ability of vanadate alone to cause the formation of FcRF $\gamma$, both in vitro and in vivo, is the first example of an agent that can initiate a specific IFN- $\gamma$-induced signal by bypassing the receptor. This agent not only activates transcription factors (FcRFy and ISGF3) but also is sufficient to increase the corresponding cellular RNAs for the ISG54 and GBP genes. The inability of vanadate to induce FcyRI RNA may be due to the requirement for other tissue-specific factors which do not interact with the GRR in order to initiate transcription (19), whereas IFN- $\alpha$-activated gene expression requires only binding to the ISRE. This is also supported by the observation that vanadate also induced expression of GBP RNA, a gene that requires only an overlapping ISRE and gamma activating sequence element in its promoter for IFN inducibility (5). It remains to be determined whether vanadate induces FcRF $\gamma$ formation by directly activating a tyrosine kinase or by inhibiting a constitutively active tyrosine phosphatase(s). Since vanadate also induces the formation of ISGF3 in monocyte membranes and not in HeLa cells (where it actually inhibits IFN- $\alpha$-induced ISGF3 formation), monocytes like T cells $(7,18)$ or neutrophils $(11)$ may have a high level of constitutively active tyrosine phosphatases. By inhibiting these phosphatases, vanadate may allow for the simultaneous activation of a kinase necessary for the induction of FcRF $\gamma$ and a decrease in phosphatase-induced degradation of $\mathrm{FCRF} \gamma$.

In contrast to the formation of the complete IFN- $\alpha$ induced complex (ISGF3), which requires both membraneassociated proteins (ISGF3 $\alpha$ ) and a cytosolic DNA-binding component (ISGF3 $\gamma$ ) (3), the activation of the FcRF $\gamma$ complex takes place entirely on a membrane fraction. This finding suggests that all the components necessary for IFN- $\gamma$ to initiate a transmembrane signal must be localized to the membrane fraction. This would include, in addition to the $90-\mathrm{kDa}$ receptor that binds IFN- $\gamma$, a tyrosine kinase, the FcRF $\gamma$ transcription factors (i.e., the $91-$ and 43-kDa proteins), and possibly a tyrosine phosphatase. Although a tyrosine protein kinase (tyk2) has been recently implicated in the signal transduction pathway for IFN- $\alpha$ (27), no related (jakl or jak2 family) or unrelated tyrosine kinase (src family) has been specifically identified with the IFN- $\gamma$ signalling cascade. Of interest is the finding that jak1 mRNA (29) and the $s r c$-like kinase, $h c k(1)$, can be specifically upregulated in monocytes by treatment with IFN- $\gamma$. However, no data as yet link either kinase to the immediate events surrounding IFN- $\gamma$ signal transduction.

The FcRF $\gamma$ complex consists of at least two protein components: (i) the $91-\mathrm{kDa}$ protein, a tyrosine-phosphorylated protein that is part of the ISGF $3 \alpha$ complex, and (ii) a 43-kDa protein that binds specifically to the GRR. Although it is not known whether the $43-\mathrm{kDa}$ component is modified by the binding of IFN- $\gamma$ to its receptor, this protein is clearly different from ISGF3 $\gamma$, its counterpart in the ISGF3 complex. Whereas the ISGF3 $\gamma$ component is $N$-ethylmaleimide sensitive (with respect to DNA binding) (19), the $43-\mathrm{kDa}$ component is not (data not shown), nor does the ISRE competitively inhibit the binding of FcRF $\gamma$ to the GRR (27). In addition, ISGF3 $\gamma$ is constitutively expressed in the cytoplasm and nucleus, and the 43-kDa GRR-binding component is clearly part of the membrane fraction. The $91-\mathrm{kDa}$ protein is also a part of the IFN- $\gamma$-activated transcription factor, GAF (22). It is conceivable that proteins such as the $91-\mathrm{kDa}$ protein are tyrosine phosphorylated in response to either IFN- $\gamma$ or IFN- $\alpha$ and then act as cofactors to enhance the affinity of specific sets of DNA-binding proteins for their promoter elements. The specificity of gene activation for a given cytokine may, therefore, require both a combination of cofactor proteins activated by tyrosine phosphorylation upon ligand binding and the availability of specific sets of DNA-binding proteins, the latter of which may either be tissue specific or sequestered within particular subcellular compartments.

\section{ACKNOWLEDGMENTS}

We thank the Schering Corp., Kenilworth, N.J., for supplying recombinant human GMCSF; Genentech, Inc., South San Francisco, Calif., for supplying recombinant human IFN- $\gamma$; Gianni Garotta, Hoffmann LaRoche, Basel, Switzerland, for providing antibodies against the IFN- $\gamma$ receptor; and Jack E. Dixon (University of Michigan, Ann Arbor) for supplying recombinant protein tyrosine phosphatase. We thank G. Feldman and H. Metzger for critically reading the manuscript.

M.D. was supported by a Schroedinger fellowship from the Fonds zur Foerderung der wissenschaftlichen Forschung of Austria.

\section{REFERENCES}

1. Boulet, I., S. Ralph, E. Stanley, P. Lock, A. R. Dunn, S. P. Green, and W. A. Phillips. 1992. Lipopolysaccharide- and interferon-gamma induced expression of $h c k$ and $h y n$ tyrosine kinases in murine bone marrow-derived macrophages. Oncogene 7:703-710.

2. Cheng, Y. E., C. E. Patterson, and P. Staeheli. 1991. Interferoninduced guanylate-binding proteins lack a $N(T) K X D$ consensus motif and bind GMP in addition of GDP and GTP. Mol. Cell. Biol. 11:4717-4725.

3. David, M., and A. C. Larner. 1992. Activation of transcription factors by interferon alpha in a cell free system. Science 257:813-815

4. David, M., G. Romero, Z.-Y. Zhang, J. E. Dixon, and A. C. Larner. 1993. In vitro activation of the transcription factor ISGF3 by IFN $\alpha$ involved a membrane associated tyrosine phosphatase and tyrosine kinase. J. Biol. Chem. 268:6593-6599.

5. Decker, T., D. J. Lew, Y.-S. E. Cheng, D. E. Levy, and J. E. Darnell, Jr. 1989. Interactions of $\alpha$ - and $\gamma$-interferon in the transcriptional regulation of the gene encoding a guanylatebinding protein gene. EMBO J. 8:2009-2014.

6. Finbloom, D. S., A. C. Larner, Y. Nakagawa, and D. L. Hoover. 1993. Culture of human monocytes in granulocyte-macrophage CSF results in enhancement of IFN $\gamma$ receptors but suppression 
of IFN $\gamma$-induced expression of the gene, IP-10. J. Immunol. 150:2383-2390.

7. Garcia-Morales, P., Y. Minami, E. Luong, R. D. Klausner, and L. E. Samelson. 1990. Tyrosine phosphorylation in T cells is regulated by a phosphatase activity: studies with phenylarsine oxide. Proc. Natl. Acad. Sci. USA 87:9255-9259.

8. Garotta, G., L. Ozman, M. Fountoulakis, Z. Dembic, A. P. van Loon, and D. Stuber. 1990. Human interferony receptor. Mapping of epitopes recognized by neutralizing antibodies using native and recombinant receptor proteins. J. Biol. Chem. 265: 6908-6915.

9. Gordon, J. A. 1991. Use of vanadate as a protein-phosphotyrosine phosphatase inhibitor. Methods Enzymol. 201:477-482.

10. Graber, M., C. A. June, L. E. Samelson, and A. Weiss. 1992. The protein tyrosine kinase inhibitor herbimycin $\mathrm{A}$, but not genistein, specifically inhibits signal transduction by the $T$ cell antigen receptor. Int. Immunol. 4:1201-1210.

11. Grinstein, S., W. Furuya, D. J. Lu, and G. B. Mills. 1990. Vanadate stimulates oxygen consumption and tyrosine phosphorylation in electropermeabilized human neutrophils. J. Biol. Chem. 265:318-327.

12. Guan, K., and J. E. Dixon. 1990. Protein tyrosine phosphatase activity of an essential virulence determinant in Yersinia. Science 249:553-556.

13. Hainaut, P., S. Giorgetti, A. Kowalski, and E. Van Obberghen. 1991. Insulin-like effects of vanadate on glucose uptake and on maturation in Xenopus laevis oocytes. Cell Regul. 2:317-327.

14. Heffetz, D., I. Bushkin, R. Dror, and Y. Zick. 1990. The insulinomimetic agents $\mathrm{H}_{2} \mathrm{O}_{2}$ and vanadate stimulate protein tyrosine phosphorylation in intact cells. J. Biol. Chem. 265: 2896-2902.

15. Igarashi, K., M. David, D. S. Finbloom, and A. C. Larner. 1993. In vitro activation of the transcription factor gamma interferonactivating factor by gamma interferon: evidence for a tyrosine phosphatase/kinase signaling cascade. Mol. Cell. Biol. 13:1634 1640.

16. Metzger, H. 1991. Fc receptors and membrane immunoglobulin. Curr. Opin. Immunol. 3:40-46.

17. Murray, H. 1992. The interferons, macrophage activation, and host defense against nonviral pathogens. J. Interferon Res. 12:319-322.

18. O'Shea, J. J., D. W. McVicar, T. L. Bailey, C. Burns, and M. J. Smyth. 1992. Activation of human peripheral blood T lympho- cytes by pharmacological induction of protein-tyrosine phosphorylation. Proc. Natl. Acad. Sci. USA 89:10306-10310.

19. Pearse, R. N., R. Feinman, and J. V. Ravetch. 1991. Characterization of the promoter of the human gene encoding the highaffinity IgG receptor: transcriptional induction by $\gamma$-interferon is mediated through common DNA response elements. Proc. Natl. Acad. Sci. USA 88:11305-11309.

20. Petricoin, E. F., R. H. Hackett, H. Akai, K. Igarashi, D. S. Finbloom, and A. C. Larner. 1992. Modulation of interferon signalling in human fibroblasts by phorbol esters. Mol. Cell. Biol. 12:4486-4495.

21. Ravetch, J. V., and J.-P. Kinet. 1991. Fc receptors. Annu. Rev. Immunol. 9:457-492.

22. Schindler, C., X.-Y. Fu, T. Improta, R. Aebersold, and J. E. Darnell, Jr. 1992. Proteins of transcription factor ISGF-3: one gene encodes the 91 - and $84-\mathrm{kDa}$ ISGF-3 proteins that are activated by interferon $\alpha$. Proc. Natl. Acad. Sci. USA 89:78367839.

23. Schindler, C., K. Shuai, V. R. Prezioso, and J. E. Darnell, Jr. 1992. Interferon-dependent tyrosine phosphorylation of a latent cytoplasmic transcription factor. Science 257:809-813.

24. Shuai, K., C. Schindler, V. R. Prezioso, and J. E. Darnell, Jr. 1992. Activation of transcription by IFN $\gamma$ : tyrosine phosphorylation of a $91 \mathrm{kDa}$ DNA binding protein. Science 258:1808-1812.

25. Tamura, S., T. A. Brown, J. A. Whipple, Y. Fugita-Yamaguchi, R. E. Dubler, K. Cheng, and J. Larner. 1984. A novel mechanism for the insulin-like effect of vanadate on glycogen synthase in rat adipocytes. J. Biol. Chem. 259:6650-6658.

26. Unkeless, J. C., E. Scigliano, and V. H. Freedman. 1988. Structure and function of human and murine receptors for IgG. Annu. Rev. Immunol. 6:251-281.

27. Velazquez, L., M. Fellous, G. R. Stark, and S. Pellegrini. 1992. A protein tyrosine kinase in the interferon $\alpha / \beta$ signaling pathway. Cell 70:313-322.

28. Wilson, K. C., and D. S. Finbloom. 1992. Interferony rapidly induces in human monocytes a novel DNA-binding factor that recognizes the gamma response region within the promoter of the gene for the high affinity Fc $\gamma$ receptor. Proc. Natl. Acad. Sci. USA 89:11964-11968.

29. Zack Howard, O. M., M. Dean, H. Young, M. Ramsburg, J. A. Turpin, D. F. Michiel, D. J. Kelvin, L. Lee, and W. L. Farrar. 1992. Characterization of a class 3 tyrosine kinase. Oncogene 7:895-900. 